\title{
CD57-Positive Neoplastic Cells Present
}

National Cancer Institute

\section{Source}

National Cancer Institute. CD57-Positive Neoplastic Cells Present. NCI Thesaurus. Code C71619.

An indication that expression of CD57 has been detected in a sample of neoplastic cells. 